\title{
THE INFLUENCE OF FERTILIZATION ON QUALITY OF INFLORESCENCES OF EASY POT FREESIA (Freesia Eckl. ex Klatt) GROWN FROM ADVENTITIOUS CORMS
}

\author{
Piotr Żurawik, Monika Placek \\ Study of Ornamental Plants in the Department of Horticulture West Pomeranian University of Technology in Szczecin \\ 71-459 Szczecin, Papieża Pawła VI 1, Poland, e-mail: piotr.zurawik@zut.edu.pl
}

Received: 20.032011

\begin{abstract}
The experiments were carried out in 2006-2007, in the spring-summer season, in an unheated plastic tunnel. Adventitious corms of Easy Pot Freesia: 'Gompey', 'Popey' and 'Suzy', were the plant material. The influence of a traditional fertilizer Azofoska and slow-release fertilizers, Osmocote Plus 5/6, Osmocote Exact and Polyon 5/6, on the ornamental value of plants was evaluated. All fertilizers were applied at rates of 2.5

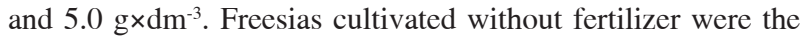
control plants.

The cultivar 'Gompey' was characterized by longer inflorescence shoots and flowers of greater diameter, while the cultivar 'Suzy' had more flowers than the plants of the other cultivars evaluated. Plants with the greatest number of flowers and the longest inflorescences and shoots were obtained when slow-release fertilizers Osmocote Plus 5/6 and Osmocote Exact were used, regardless of cultivar and fertilizer dose. Polyon was useless for freesia fertilization, since it resulted in a decrease of the ornamental value of plants. Plants fertilized with Polyon had fewer flowers, additionally with a smaller diameter, and their inflorescences were shorter and deformed.
\end{abstract}

Key words: freesia, Easy Pot Group, fertilization, flowering

\section{INTRODUCTION}

Easy Pot freesias are an interesting supplement of the assortment of ornamental pot plants used in interior decoration. They can be offered in the market all the year round (Startek et al. 2000; $\dot{Z}$ u rawik et al. 2003; $\dot{Z}$ u r a w i k, 2008). Nutritional requirements of freesia are dependent to a high degree on developmental stage and cultivar (Wojcieszczuk et al. 2000). Some growers recommend Osmocote Plus fertilizer at a rate of about 3-4 $\mathrm{g} \times \mathrm{dm}^{-3}$ for cultivation of Easy Pot Freesia (A n o n i m u s, 1997). According to
Startek (2002) as well as Startek and $\dot{Z}$ u rawik (2002), fertilizers from the Osmocote group: Osmocote Plus and Osmocote Exact, are also useful for freesia cultivation. De Hertogh (2001) is of the opinion that Osmocote fertilizers can be replaced by other fertilizers in the cultivation of Easy Pot Freesia and other fertilizers can be applied in the same rates and proportions of $\mathrm{N}: \mathrm{P}: \mathrm{K}$ as in the cultivation of freesia for cut flower. In the present experiments, large subsequent corms of freesia were usually used (S tartek and $\dot{Z}$ u r a w i k, 2002). However, there is a lack of information about the influence of fertilization on flowering of freesia cultivated from adventitious corms.

The aim of this research was to examine the influence of selected slow-release fertilizers and Azofoska as well as their rates on the quality of inflorescences of Easy Pot Freesia cultivated from adventitious corms in the spring-summer season.

\section{MATERIALS AND METHODS}

The experiments were conducted in the spring-summer season (from April to September) in the period 2006-2007. Adventitious corms of three cultivars of Easy Pot Freesia (Freesia Eckl. ex Klatt) from a Dutch company Royal van Zanten (currently Van den Bos) were the plant material. In the first year of the research, the average weight of corms of 'Gompey' freesias reached $0.63 \mathrm{~g}$, 'Popey' $-0.81 \mathrm{~g}$, and 'Suzy' $-1.09 \mathrm{~g}$, but in the second year of the experiments, this value was as follows: 'Gompey' $-0.92 \mathrm{~g}$, 'Popey' $-1.23 \mathrm{~g}$ and 'Suzy' $-1.53 \mathrm{~g}$. Before planting, corms were prepared in a room with air temperature between 28 and $30^{\circ} \mathrm{C}$ and relative air moisture of $80-85 \%$. Corms were planted when they had formed swollen apical buds and perceptible root boots. 
Corms were planted to $12-\mathrm{cm}$ pots, filled with medium prepared of sphagnum peat deacidified with $7.0 \mathrm{~g} \mathrm{x} \mathrm{dm}^{-3}$ chalk and $5.0 \mathrm{~g} \times \mathrm{dm}^{-3}$ dolomite to a of $\mathrm{pH}$ 6.2. Sphagnum peat (with a $\mathrm{pH}$ of 3.6) before deacidifying was characterized by the following contents of chemical components (in $\mathrm{mg} \times \mathrm{dm}^{-3}$ ): $\mathrm{N}^{-N} \mathrm{~N}_{3}-16.5$, $\mathrm{P}-27.0, \mathrm{~K}-10.2, \mathrm{Mg}-25.3, \mathrm{Ca}-58.0, \mathrm{Cl}-37.0$. Just before planting corms, multi-component mineral fertilizers were used to supplement the deficiency of nutritive components: traditional fertilizer Azofoska $(13.6+6.4+19.1+$ microelements $)$ and slow-release fertilizers - Osmocote Plus 5/6 $(15+10+12+2+$ microelements), Osmocote Exact $(15+8+10+3+$ microelements), Polyon 5/6 $(17+11+9+$ microelements). All fertilizers were applied at two rates: 2.5 and $5.0 \mathrm{~g} \times \mathrm{dm}^{-3}$. Control plants were cultivated without fertilizer. Pots with planted corms were put on the cultivation tables in the unheated plastic tunnel.

Measurements of plant traits were conducted when the first flower in an inflorescence developed. Measurements were made of total length of the main inflorescence shoot, length of the first inflorescence shoot, inflorescence length in the first inflorescence shoot, number of flowers in the first inflorescence, diameter of the first flower in the inflorescence.

30 experimental treatments ( 3 cultivars $\mathrm{x} 5$ fertilizers $x 2$ fertilizer rates) were evaluated in the research. Each treatment consisted of 20 corms, divided into 4 replications, with 5 corms in each pot. The experiments were established using a completely randomized design.

The results were statistically verified using a three-factorial analysis of variance and evaluated by multiple Tukey's test at the significance level $\alpha=0.05$.

\section{RESULTS AND DISCUSSION}

In the experiments conducted by $\mathrm{Startek}$ and $\dot{Z} u$ rawik (2002), fertilization did not affect the length of the main inflorescence shoot of freesia cultivated from subsequent corms. However, in our own experiments when plants were cultivated from adventitious corms there was a significant influence of fertilizers and their doses on length of inflorescence shoots. In 2006 and in 2007, plants grown in medium with the addition of Osmocote Exact were characterized by the longest shoots; however, control freesias and plants fertilized with Polyon had the shortest shoots, regardless of cultivar and fertilizer rate (Table 1). The obtained results are in agreement with $S \mathrm{tartek}$ and $\dot{Z}$ urawik (2002) and $\dot{Z}$ urawik (2009). According to these authors, fluorine in Polyon decreases the decorative value of plants. Moen (1999) is of the opinion that even small contents of this element in medium can damage plants. In both years of the study, freesias fertilized at a higher rate of the fertili- zer, i.e. $5.0 \mathrm{~g} \times \mathrm{dm}^{-3}$, were characterized by longer inflorescence shoots. In the experiments conducted by S t a r te k and $\dot{Z}$ u raw ik (2002), length of the main inflorescence shoot was dependent on cultivar traits. The results of our own experiments are conformable with this opinion. In the years 2006 and 2007, 'Gompey' freesias were characterized by the longest shoots, whereas 'Popey' freesias had the shortest shoots, regardless of fertilization. In both years of the study, the cultivars reacted differently to fertilizers and their doses. In the years 2006 and 2007, 'Popey' freesias had longer main inflorescence shoots when grown in medium with a higher dose of fertilizer, i.e. $5.0 \mathrm{~g} \times \mathrm{dm}^{-}$ ${ }^{3}$, regardless of fertilizer type. No such correlation was found in the case of the other evaluated cultivars (Fig. 1).

In our own experiments, length of the first inflorescence shoot was dependent on the type of fertilizer. However, no significant influence of fertilizer dose on this trait was found (Table 2). In both years of the study, plants cultivated in media with the addition of Osmocote Plus and Osmocote Exact were characterized by a longer first inflorescence shoot, regardless of cultivar and fertilizer rate. However, control freesias and plants cultivated in media supplemented with Azofoska and Polyon had a shorter first inflorescence shoot. According to S t a r te k et al. (2000), an increase in the weight of maternal corms planted affects the growth of plants. In the second year of our experiments, corms of greater mass were planted and plants were obtained characterized by, on average, $17 \%$ longer shoots than in the first year of the experiment when corms of smaller mass were planted. In the conducted research, length of the inflorescence shoot depended on the cultivar. Both in 2006 and 2007, the cultivars responded differently to fertilizers.

The results of our experiments did not confirm the results of experiments conducted by $\mathrm{S} t$ a r $\mathrm{t} e \mathrm{k}$ and $\dot{Z}$ u r a w i k (2002). According to these authors, fertilization does not affect the length of inflorescences of Easy Pot Freesia. However, these authors used large subsequent corms in their experiments. In our experiments, adventitious corms of smaller mass were used and in both years all fertilizers had an effect on the increase of inflorescence length in comparison with the control (Table 3). In 2006 plants cultivated in media with the addition of Osmocote Plus and Osmocote Exact and in 2007 freesias grown in medium supplemented with Osmocote Plus had the longest inflorescences. Both in 2006 and 2007, control plants were characterized by the shortest inflorescences. According to Startek and Ż urawik (2002) as well as $\dot{Z} u$ rawik et al. (2003) inflorescence length is dependent on cultivar traits. A similar dependence was found in our research. In both years, there was interaction between fertilizer type and rate. High fluorine 
concentration in medium usually results in plants drying out and dying (De Hertogh, 2001). S tartek and Żurawik (2002) as well as Ż u rawik (2009) described typical damage to freesia caused by fluorine due to the use of Azofoska and Polyon. The results of our experiments are in agreement with these authors. In 2006, when Azofoska and Polyon were used at a rate of $5.0 \mathrm{~g} \times \mathrm{dm}^{-3}$ it was found that inflorescences formed improperly and were shorter than in the case when the doses of $2.5 \mathrm{~g} \times \mathrm{dm}^{-3}$ were used. Deformations relate to the tops of inflorescences which are twisted and contorted at different angles and buds set on them bronze, do not develop, become deformed and dry out prematurely. A different response to fertilizer of the cultivars in question was found only in 2006 (Fig. 2). 'Gompey' and 'Suzy' freesias had longer inflorescences when grown in media with the addition of fertilizers at a rate of $5.0 \mathrm{~g} \times \mathrm{dm}^{-3}$. However, 'Popey' freesias were characterized by longer inflorescences when cultivated in media supplemented with fertilizers at a rate of $2.5 \mathrm{~g} \times \mathrm{dm}^{-3}$.

According to Starte k et al. (2002), diameter of Easy Pot Freesia flowers is dependent on fertilizer type and rate. The results of our experiments are in agreement with this opinion. All fertilizers applied in both years of the experiments had an effect on the increase in the diameter of freesia flowers in comparison with control plants grown without fertilizer (Table 4). Among four fertilizers used in the study, larger diameter flowers were obtained when Osmocote Plus and Osmocote Exact were used, regardless of cultivar and rate. Smaller flowers were obtained when freesias were fertilized with Azofoska and Polyon. Both in 2006 and 2007, freesias fertilized at a higher rate of fertilizer, i.e. $5.0 \mathrm{~g} \times \mathrm{dm}^{-3}$, were characterized by larger flowers. In the experiments conducted by $\dot{Z} \mathrm{u} \mathrm{r} \mathrm{a} \mathrm{w} \mathrm{i} \mathrm{k}$ et al. (2003), when freesias were cultivated from large subsequent corms, cultivar traits did not affect flower diameter. However, in our experiments in the years 2006 and 2007, flower diameter was dependent on cultivar, regardless of the size of corms planted. In both years, a different response of the cultivars to fertilizers applied was found. However, no interaction between fertilizer type and rate was found.

The opinion of S tarte k et al. (2002) that the number of flowers in the first inflorescences is dependent on fertilizer type was confirmed in our experiments. In 2006 plants grown in medium with the addition of Osmocote Exact and in 2007 freesias cultivated in medium supplemented with Osmocote Plus were characterized by the greatest number of flowers (Table 5). Control plants had the lowest number flowers in both years of the experiment and in 2007 also freesias grown in medium with the addition of Polyon. In the experiments conducted by $\dot{Z}$ u rawik et al. (2003), number of flowers of Easy Pot Freesia was dependent on cultivar. The results of our experiments confirmed this opinion. In both years, 'Popey' freesias had more flowers in the first inflorescence. In the conducted experiments, a different response of the cultivars to fertilizers was found. Interaction between cultivar and fertilizer rate was found only in 2006 (Fig. 3). 'Popey' Freesias were characterized by a greater number of flowers in the inflorescence when a higher dose of fertilizer was used, i.e. $5.0 \mathrm{~g} \times \mathrm{dm}^{-3}$.

$\dot{Z}$ u rawik et al. (2003) are of the opinion that the size of planted corms affects plant traits of Easy Pot Freesia. According to S t a r t e k et al. (2000), freesias grown from larger corms flower more abundantly than plants cultivated from smaller corms. The results of our experiments are in agreement with this opinion. In 2007, when freesias were grown from larger corms, the plants had more flowers by $12.9 \%$, on average, than in 2006 when smaller corms were planted, regardless of cultivar and fertilization. In the experiments conducted by $\mathrm{S}$ tarte $\mathrm{k}$ et al. (2002), fertilizer type affected the number of flowers of Easy Pot Freesia. In our experiments, a similar correlation was found. All fertilizers evaluated had an effect on the increase in the number of flowers in comparison with control plants which were not fertilized. In freesia cultivation, a proper amount of nitrogen is important during flowering of plants; however, potassium fertilization can be stopped ( $\mathrm{Rupprecht}, 1988$ ). Chohura (2004) is of the opinion that balanced supply of nutrients during the whole growing period can be ensured by the use of slow-release fertilizers. The results of our experiments are in agreement with this opinion. In both years of the study, freesias cultivated in media supplemented with Osmocote Plus and Osmocote Exact flowered most abundantly, regardless of cultivar. According to S tartek et al. (2002), the application of Polyon affects the decrease in flowering. In our experiment, an identical correlation was found. Plants cultivated in medium with the addition of Polyon flowered poorly, regardless of cultivar. In the experiments conducted by $\mathrm{S}$ tartek and $\dot{\mathrm{Z}} \mathrm{uraw}$ ik (2005) as well as $\dot{\mathrm{Z}} \mathrm{u}$ rawik et al. (2003), flowering of Easy Pot Freesia cultivated from large subsequent corms was dependent on cultivar traits. These results are in agreement with those obtained in our experiments. In 2006 'Gompey' and 'Popey' freesias had more flowers than 'Suzy' freesias. However, in 2007 'Popey' freesias were characterized by the greatest number of flowers and 'Suzy' freesias by the smallest number of flowers. In both years, interactions were found between cultivar and fertilizer type as well as between fertilizer type and rate. Easy Pot Freesia can be recommended for pot cultivation on the condition that the concentration of plants is increased, even though plants obtained from cormlets flower more poorly than freesias cultivated from adventitious corms. 
Table 1

Length of the main inflorescence shoot $(\mathrm{cm})$ of Easy Pot Freesia cultivars depending on fertilizer type and rate

\begin{tabular}{|c|c|c|c|c|c|c|c|}
\hline \multirow{2}{*}{ Year } & \multirow{2}{*}{$\begin{array}{c}\text { Type of } \\
\text { fertilizer }(C)\end{array}$} & \multicolumn{3}{|c|}{ Cultivar (A) } & \multicolumn{2}{|c|}{ Rate of fertilizer $(\mathrm{B})\left(\mathrm{g} \times \mathrm{dm}^{-3}\right)$} & \multirow{2}{*}{ Mean } \\
\hline & & Gompey & Popey & Suzy & 2.5 & 5.0 & \\
\hline \multirow{7}{*}{2006} & Control* & 14.2 & 18.7 & 18.2 & 16.9 & 17.1 & $\mathbf{1 7 . 0}$ \\
\hline & Azofoska & 24.4 & 20.3 & 23.1 & 22.4 & 22.8 & 22.6 \\
\hline & Osmocote Plus & 26.7 & 19.8 & 24.7 & 22.6 & 24.9 & 23.7 \\
\hline & Osmocote Exact & 31.5 & 21.8 & 21.8 & 24.1 & 26.0 & 25.0 \\
\hline & Polyon & 17.3 & 16.9 & 18.6 & 17.4 & 17.8 & 17.6 \\
\hline & Mean & 22.8 & 19.5 & 21.3 & 20.7 & 21.7 & \\
\hline & $\operatorname{LSD}_{\alpha 0.05}$ & A-0.70 B- 0.48 & C-1.07 A(B)-1.00 & $\mathrm{B}(\mathrm{A})-0.82$ & $\mathrm{~A}(\mathrm{C})-1.00$ & $\mathrm{C}(\mathrm{A})-1.17 \quad \mathrm{~B}(\mathrm{C})-1.06$ & $\mathrm{C}(\mathrm{B})-1.51$ \\
\hline \multirow{7}{*}{2007} & Control* & 16.3 & 20.8 & 22.2 & 19.3 & 20.2 & 19.8 \\
\hline & Azofoska & 26.4 & 22.4 & 24.9 & 24.0 & 25.2 & 24.6 \\
\hline & Osmocote Plus & 28.2 & 23.4 & 24.9 & 24.3 & 26.8 & 25.5 \\
\hline & Osmocote Exact & 36.1 & 24.8 & 23.2 & 26.8 & 29.3 & 28.0 \\
\hline & Polyon & 17.7 & 18.4 & 20.6 & 19.1 & 18.8 & 18.9 \\
\hline & Mean & 24.9 & 22.0 & 23.2 & 22.7 & 24.0 & \\
\hline & $\operatorname{LSD}_{\alpha 0.05}$ & A- $-0.85 \quad$ B- -0.58 & C-1.29 A(B)-1.21 & $\mathrm{B}(\mathrm{A})-1.00$ & $\mathrm{~A}(\mathrm{C})-1.42$ & $\mathrm{C}(\mathrm{A})-1.21 \quad \mathrm{~B}(\mathrm{C})-1.83$ & $\mathrm{C}(\mathrm{B})-1.29$ \\
\hline
\end{tabular}

Explanations: *no fertilizer; **n.s. - differences not significant

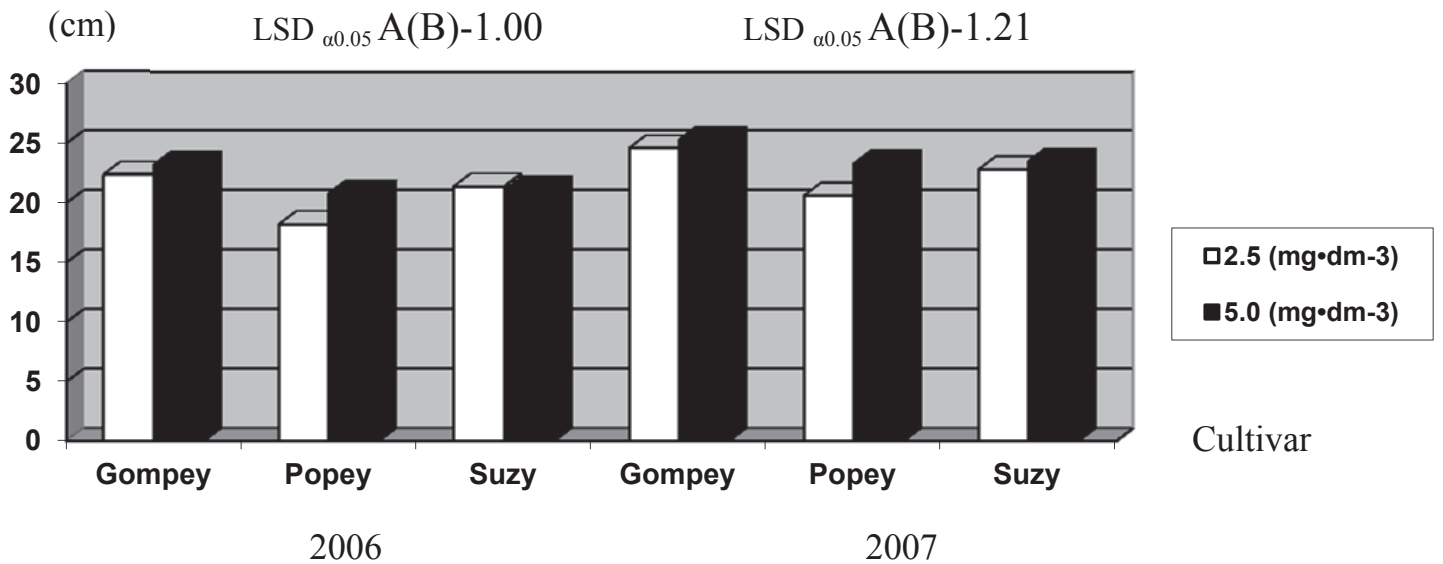

Fig. 1. Length of the main inflorescence shoot $(\mathrm{cm})$ of Easy Pot Freesia cultivars depending on fertilizer rate

Table 2

Length of the first inflorescence shoot $(\mathrm{cm})$ of Easy Pot Freesia cultivars depending on fertilizer type and rate

\begin{tabular}{|c|c|c|c|c|c|c|c|}
\hline \multirow{2}{*}{ Year } & \multirow{2}{*}{$\begin{array}{c}\text { Type of } \\
\text { fertilizer }(\mathrm{C})\end{array}$} & \multicolumn{3}{|c|}{ Cultivar (A) } & \multicolumn{2}{|c|}{ Rate of fertilizer (B) $\left(\mathrm{g} \times \mathrm{dm}^{-3}\right)$} & \multirow{2}{*}{ Mean } \\
\hline & & Gompey & Popey & Suzy & 2.5 & 5.0 & \\
\hline \multirow{7}{*}{2006} & Control* & 5.73 & 6.20 & 7.45 & 6.47 & 6.45 & 6.46 \\
\hline & Azofoska & 7.95 & 5.35 & 6.73 & 6.27 & 7.08 & 6.68 \\
\hline & Osmocote Plus & 11.00 & 7.00 & 7.35 & 8.37 & 8.53 & 8.45 \\
\hline & Osmocote Exact & 10.48 & 7.80 & 7.18 & 8.45 & 8.52 & 8.48 \\
\hline & Polyon & 8.03 & 6.28 & 6.50 & 6.88 & 6.98 & 6.93 \\
\hline & Mean & 8.64 & 6.53 & 7.04 & 7.29 & 7.51 & \\
\hline & $\operatorname{LSD}_{\alpha 0.05}$ & A-0.410 B-n.s.** & C-0.622 & AxB-n.s. $A(C)-0.579$ & $9 \mathrm{C}(\mathrm{A})-0.682$ & BxC-n.s. & \\
\hline \multirow{7}{*}{2007} & Control* & 7.88 & 7.33 & 9.58 & 8.38 & 8.13 & 8.26 \\
\hline & Azofoska & 10.60 & 6.70 & 8.03 & 8.40 & 8.48 & 8.44 \\
\hline & Osmocote Plus & 12.90 & 9.10 & 8.20 & 9.80 & 10.33 & 10.07 \\
\hline & Osmocote Exact & 13.30 & 9.13 & 8.63 & 10.12 & 10.58 & 10.35 \\
\hline & Polyon & 8.10 & 7.38 & 6.80 & 7.70 & 7.15 & 7.43 \\
\hline & Mean & 10.56 & 7.93 & 8.25 & 8.88 & 8.94 & \\
\hline & $\operatorname{LSD}_{\alpha 0.05}$ & A-0.727 B-n.s. & $-1.105 \mathrm{~A}$ & xB-n.s. $\mathrm{A}(\mathrm{C})-1.028 \mathrm{C}$ & $\mathrm{C}(\mathrm{A})-1.210 \mathrm{~B}$ & $x C-n . s$. & \\
\hline
\end{tabular}

Explanations see Table 1. 
Table 3

Length of the inflorescence $(\mathrm{cm})$ of Easy Pot Freesia cultivars depending on fertilizer type and rate

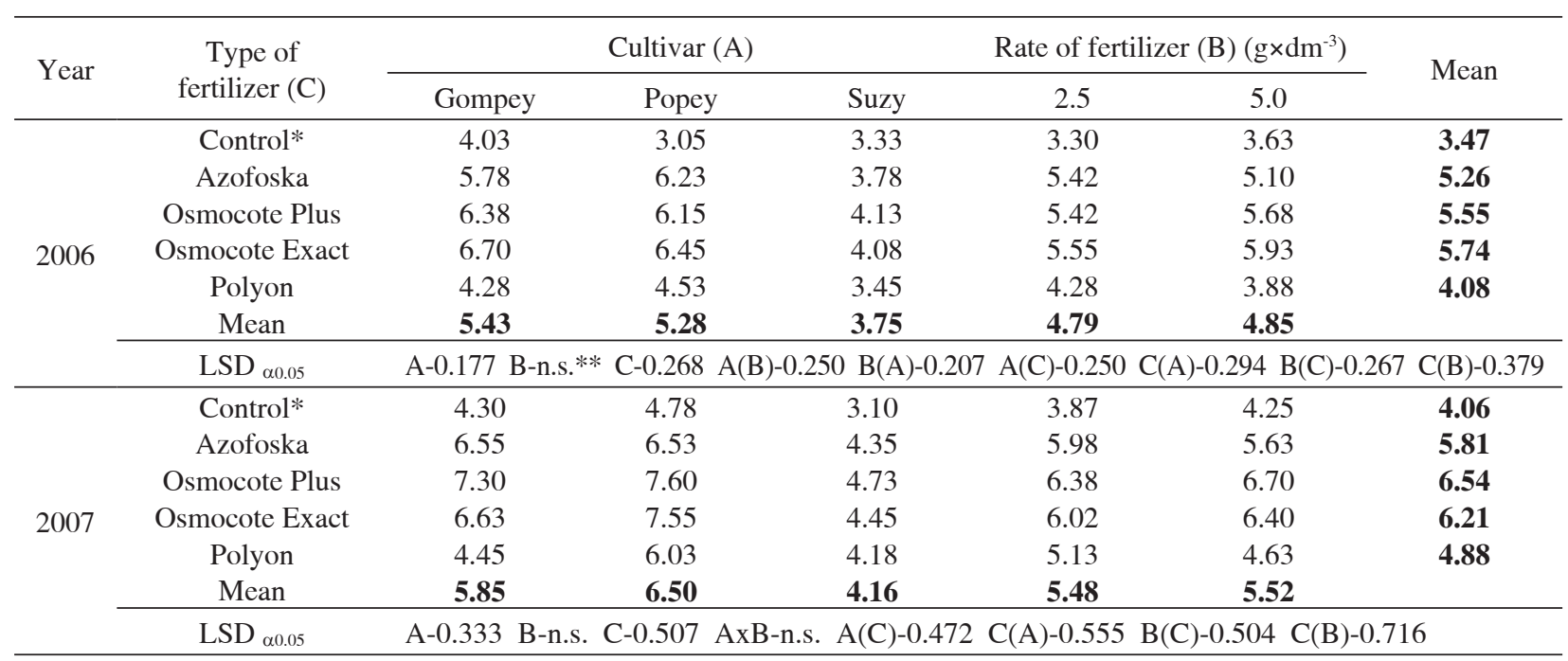

Explanations see Table 1.

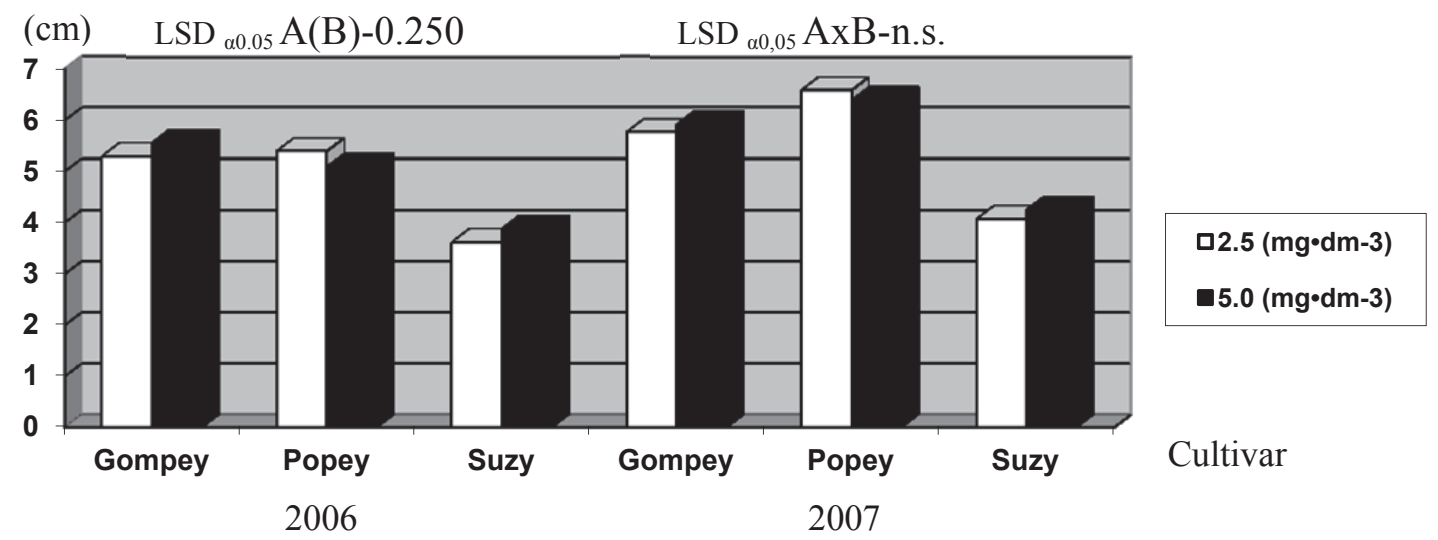

Fig. 2. Length of the inflorescence $(\mathrm{cm})$ of Easy Pot Freesia cultivars depending on fertilizer rate

Table 4

Flower diameter $(\mathrm{cm})$ of Easy Pot Freesia cultivars depending on fertilizer type and rate

\begin{tabular}{|c|c|c|c|c|c|c|c|}
\hline \multirow{2}{*}{ Year } & \multirow{2}{*}{$\begin{array}{c}\text { Type of } \\
\text { fertilizer }(\mathrm{C})\end{array}$} & \multicolumn{3}{|c|}{ Cultivar (A) } & \multicolumn{2}{|c|}{ Rate of fertilizer (B) $\left(\mathrm{g} \times \mathrm{dm}^{-3}\right)$} & \multirow{2}{*}{ Mean } \\
\hline & & Gompey & Popey & Suz & 2.5 & 5.0 & \\
\hline \multirow{7}{*}{2006} & Control* & 3.50 & 3.78 & 3.43 & 3.48 & 3.65 & 3.57 \\
\hline & Azofoska & 4.58 & 3.63 & 3.88 & 4.00 & 4.05 & 4.03 \\
\hline & Osmocote Plus & 4.65 & 4.20 & 4.45 & 4.33 & 4.53 & 4.43 \\
\hline & Osmocote Exact & 4.63 & 4.45 & 4.10 & 4.30 & 4.48 & 4.39 \\
\hline & Polyon & 4.23 & 3.70 & 4.23 & 3.90 & 4.20 & 4.05 \\
\hline & Mean & 4.32 & 3.95 & 4.02 & 4.00 & 4.18 & \\
\hline & $\operatorname{LSD}_{\alpha 0.05}$ & A- 0.082 B- 0.055 & C- 0.124 & AxB-n.s.** & $\mathrm{A}(\mathrm{C})-0.116 \mathrm{C}(\mathrm{A})$ & BxC-n.s. & \\
\hline \multirow{7}{*}{2007} & Control* & 3.70 & 4.38 & 3.73 & $3 \quad 3.90$ & 3.97 & 3.93 \\
\hline & Azofoska & 4.68 & 3.73 & 4.10 & 4.08 & 4.25 & 4.17 \\
\hline & Osmocote Plus & 4.75 & 4.35 & 4.65 & 4.50 & 4.67 & 4.58 \\
\hline & Osmocote Exact & 4.73 & 4.70 & 4.23 & 4.50 & 4.60 & 4.55 \\
\hline & Polyon & 4.20 & 4.23 & 4.35 & 4.18 & 4.33 & 4.26 \\
\hline & Mean & 4.41 & 4.28 & 4.21 & 4.23 & 4.36 & \\
\hline & $\operatorname{LSD}_{\alpha 0.05}$ & A-0.135 B-0.091 & C-0.205 & AxB-n.s. A( & C) -0.190 C(A)- 0. & xC-n.s. & \\
\hline
\end{tabular}

Explanations see Table 1. 
Table 5

Number of flowers in the first inflorescence of Easy Pot Freesia cultivars depending on fertilizer type and rate

\begin{tabular}{|c|c|c|c|c|c|c|c|c|}
\hline \multirow{2}{*}{ Year } & \multirow{2}{*}{$\begin{array}{c}\text { Type of } \\
\text { fertilizer }(\mathrm{C})\end{array}$} & \multicolumn{3}{|c|}{ Cultivar (A) } & \multicolumn{3}{|c|}{ Rate of fertilizer $(\mathrm{B})\left(\mathrm{g} \times \mathrm{dm}^{-3}\right)$} & \multirow{2}{*}{ Mean } \\
\hline & & Gompey & Popey & Suz & $z y$ & 2.5 & 5.0 & \\
\hline \multirow{7}{*}{2006} & Control* & 4.08 & 6.75 & 5.7 & 75 & 5.50 & 5.55 & 5.53 \\
\hline & Azofoska & 7.83 & 8.25 & 7.9 & & 7.78 & 8.22 & 7.99 \\
\hline & Osmocote Plus & 8.78 & 8.55 & 8.1 & & 8.22 & 8.78 & 8.49 \\
\hline & Osmocote Exact & 9.50 & 9.25 & 8.7 & & 8.87 & 9.47 & 9.17 \\
\hline & Polyon & 5.90 & 6.65 & 6.8 & & 6.52 & 6.38 & 6.45 \\
\hline & Mean & 7.22 & 7.89 & 7.4 & & 7.37 & 7.68 & \\
\hline & $\operatorname{LSD}_{\alpha 0.05}$ & A-0.438 B-0.296 & C-0.665 & $\mathrm{A}(\mathrm{B})-0.620$ & $\mathrm{~B}(\mathrm{~A})-0.513$ & $\mathrm{~A}(\mathrm{C})-0.620$ & $\mathrm{C}(\mathrm{A})-0.729$ & BxC-n.s. \\
\hline \multirow{7}{*}{2007} & Control $^{*}$ & 5.38 & 8.78 & 6.2 & & 6.92 & 6.68 & 6.80 \\
\hline & Azofoska & 9.83 & 9.38 & 8.5 & & 9.38 & 9.13 & 9.26 \\
\hline & Osmocote Plus & 11.48 & 9.50 & 9.15 & & 9.95 & 10.13 & 10.14 \\
\hline & Osmocote Exact & 10.00 & 10.00 & 9.10 & & 9.80 & 9.60 & 9.70 \\
\hline & Polyon & 6.28 & 7.63 & 7.80 & & 7.78 & 6.68 & 7.23 \\
\hline & Mean & 8.59 & 9.06 & 8.18 & & 8.77 & 8.45 & \\
\hline & $\operatorname{LSD}_{\alpha 0.05}$ & A-0.503 B-r.n.; n. & i.s. C-0.7C & 63 AxB-n.s. & $\mathrm{A}(\mathrm{C})-0,711$ & C(A)- -0.836 & BxC-n.s. & \\
\hline
\end{tabular}

Explanations see Table 1.

(cm) $\quad \operatorname{LSD}_{\alpha 0.05} \mathrm{~A}(\mathrm{~B})-0.620$

LSD ${ }_{\alpha 0.05}$ AxB-n.s.

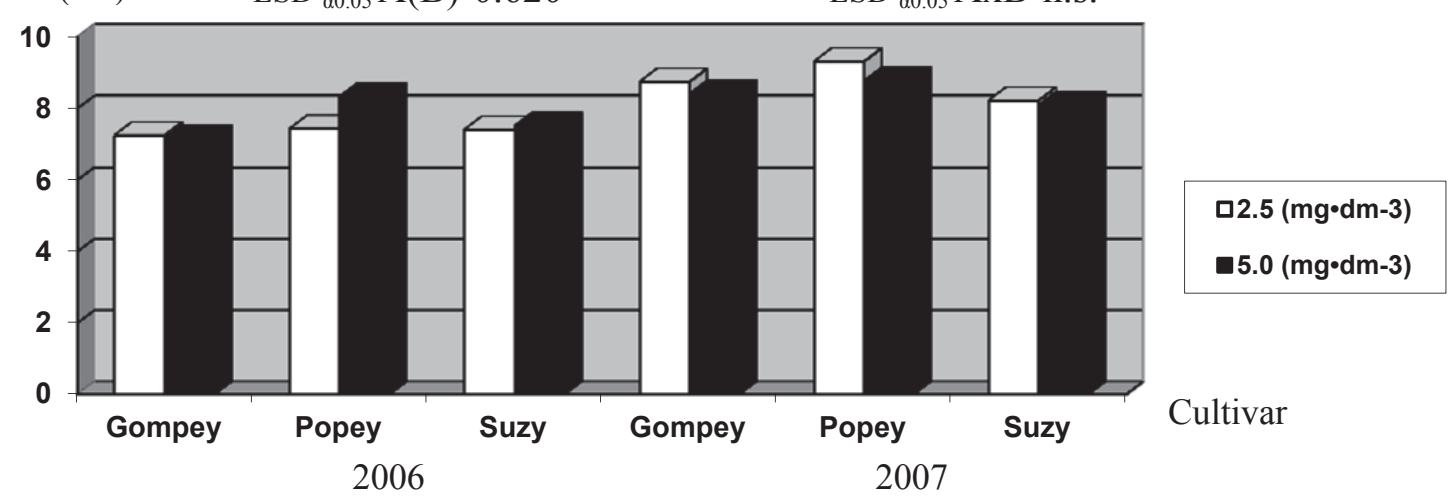

Fig. 3. Number of flowers in the first inflorescence of Easy Pot Freesia cultivars depending on fertilizer rate

Table 6

Number of flowers per plant of Easy Pot Freesia cultivars depending on fertilizer type and rate

\begin{tabular}{|c|c|c|c|c|c|c|c|}
\hline \multirow{2}{*}{ Year } & \multirow{2}{*}{$\begin{array}{c}\text { Type of } \\
\text { fertilizer }(\mathrm{C})\end{array}$} & \multicolumn{3}{|c|}{ Cultivar (A) } & \multicolumn{2}{|c|}{ Rate of fertilizer (B) $\left(\mathrm{g} \times \mathrm{dm}^{-3}\right)$} & \multirow{2}{*}{ Mean } \\
\hline & & Gompey & Popey & Suzy & 2.5 & 5.0 & \\
\hline \multirow{7}{*}{2006} & Control* & 4.2 & 7.0 & 5.3 & 5.3 & 5.6 & 5.5 \\
\hline & Azofoska & 11.6 & 9.6 & 9.7 & 11.1 & 9.6 & 10.3 \\
\hline & Osmocote Plus & 12.6 & 12.7 & 9.5 & 10.4 & 12.8 & 11.6 \\
\hline & Osmocote Exact & 13.5 & 12.4 & 10.7 & 10.8 & 13.6 & 12.2 \\
\hline & Polyon & 7.1 & 7.0 & 6.8 & 7.5 & 6.4 & 6.9 \\
\hline & Mean & 9.8 & 9.7 & 8.4 & 9.0 & 9.6 & \\
\hline & $\operatorname{LSD}_{\alpha 0.05}$ & A-0.67 B- 0.46 & C-1,02 AxB-n.s.** & $\mathrm{A}(\mathrm{C})-0.95$ & $\mathrm{C}(\mathrm{A})-1.12$ & $\mathrm{~B}(\mathrm{C})-1.02 \mathrm{C}(\mathrm{B})-1.45$ & \\
\hline \multirow{7}{*}{2007} & Control* & 5.1 & 8.7 & 5.7 & 6.5 & 6.5 & 6.5 \\
\hline & Azofoska & 12.2 & 11.8 & 11.7 & 12.5 & 11.3 & 11.9 \\
\hline & Osmocote Plus & 14.1 & 14.3 & 11.3 & 12.0 & 14.4 & 13.2 \\
\hline & Osmocote Exact & 14.0 & 15.8 & 11.9 & 12.4 & 15.4 & 13.9 \\
\hline & Polyon & 7.9 & 7.9 & 8.0 & 9.0 & 6.9 & 7.9 \\
\hline & Mean & 10.6 & 11.7 & 9.7 & 10.4 & 10.9 & \\
\hline & $\operatorname{LSD}_{\alpha 0.05}$ & A-0.73 B-n.s. & C-1.11 AxB-n.s. A & (C) $-1.03 \mathrm{C}($ & A) $-1.22 \mathrm{~B}(\mathrm{C}$ & C)-1.11 C(B)-1.57 & \\
\hline
\end{tabular}

Explanations see Table 1. 


\section{CONCLUSIONS}

The ornamental value of Easy Pot Freesia grown from adventitious corms depended on cultivar traits. The cultivar 'Gompey' was characterized by longer inflorescence shoots and flowers of greater diameter than the cultivars 'Popey' and 'Suzy', bu 'Popey' had more flowers in the first inflorescence.

The applied fertilizers affected inflorescence traits of Easy Pot Freesia, regardless of cultivar and fertilizer rate. Plants with most abundant flowering and the longest inflorescences and shoots were obtained when Osmocote Plus and Osmocote Exact were used.

Polyon resulted in a decrease in diameter and number of flowers, regardless of its dose. The obtained inflorescences were shorter, developed improperly and had a fewer number of lateral shoots.

\section{REFERENCES}

Anonimus 1997. Let's talk about freesia. Van Staaveren Aalsmeer: 9-10.

Chohura P., 2004. Nawozy wolno działające w szkółkarstwie ozdobnym. / Slow-release fertilizers in ornamental nursery. Szkółkarstwo, 4: 112-115. (in Polish)

De Hertogh A.A., 2001. Growing Freesia. Flora Culture International 12: 39-39.

Moen M., 1999. The cultivation of Freesias. Van Staaveren, Aalsmeer: 1-28.

Rupprecht H., 1988. Die Freesie. VEB Deutscher Landwirschaftsverlag Berlin: 136.

S t a r tek L., 2002. Growth dynamics and decorative value of 'Easy Pot' freesia depending on the growing conditions. Acta Hortic. 570: 385-390.

Startek L., Żurawik P., 2002. Wpływ Azofoski i nawozów o działaniu spowolnionym na dynamikę wzrostu i wartość dekoracyjną odmian frezji z grupy Easy Pot. / The influence of Azofoska and slow-release fertilizers on growth dynamics and decorative value of Easy Pot Freesia. Zesz. Prob. Post. Nauk Rol. 484: 645-651. (in Polish)

Startek L., Żurawik P., 2005. Effect of Ethephon on Easy Pot Freesia. Acta Hortic. 673: 617-623.

Startek L., Żurawik P., Rejent J., Dobrowolska A., 2000. Wpływ temperatury i długości okresu przechowywania bulw na rozwój frezji doniczkowej. / The influence of temperature and storage period of corms on the development of potted freesia. Zesz. Nauk. Inst. Sad. Kwiac. 7: 105-112. (in Polish)

Wojcieszczuk T., Startek L., Tyszkiewicz K., 2000. Wpływ podłoża na skład chemiczny liści pięciu odmian frezji ogrodowej. / Effect of growing medium on the chemical composition of leaves of five garden freesia cultivars. Rocz. AR Poznań CCCXXIII Ogrodn. 31: 189-194. (in Polish)

Żu raw i k P., 2008. Wielkość i jakość plonu bulw potomnych frezji z grupy Easy Pot w zależności od stężenia $\mathrm{GA}_{3}$. / Yield size and quality of offspring corms of Easy Pot Freesia depending on $\mathrm{GA}_{3}$ concentration. Zesz. Prob. Post. Nauk Rol. 525: 551-556. (in Polish)

Żu rawik P., 2009. Wpływ rodzaju i dawki nawozu na cechy morfologiczne frezji z grupy Easy Pot. / Influence of the type and dose of fertilizer on morphological traits of freesia from the Easy Pot group. Zesz. Prob. Post. Nauk Rol. 538: 383-390. (in Polish)

Żurawik P., Startek L., Salachna P., 2003. Wzrost, rozwój i kwitnienie w okresie letnim odmian frezji (Freesia Eckl. ex Klatt) z grupy Easy Pot. / Growth, development and flowering of Easy Pot Freesia cultivars in the summer period. Zesz. Prob. Post. Nauk Rol. 491: 403-410. (in Polish)

\section{Wpływ nawożenia na jakość kwiatostanów frezji (Freesia Eckl. ex Klatt) z grupy Easy Pot uprawianej $\mathrm{z}$ bulw przybyszowych}

\section{Streszczenie}

Badania przeprowadzono w latach 2006-2007 w terminie wiosenno-letnim, w nie ogrzewanym tunelu foliowym. Materiał wyjściowy stanowiły bulwy przybyszowe frezji należących do grupy Easy Pot: 'Gompey', 'Popey' i 'Suzy'. W doświadczeniach oceniano wpływ nawozu o działaniu tradycyjnym - Azofoska i nawozów o działaniu spowolnionym: Osmocote Plus 5/6, Osmocote Exact i Polyon 5/6 na wartość ozdobną roślin. Wszystkie nawozy zastosowano w dwóch dawkach 2,5 i 5,0 $\mathrm{g} \times \mathrm{dm}^{-3}$. Wariant bez nawożenia stanowił kontrolę.

Frezje odmiany 'Gompey' odznaczały się dłuższymi pędami kwiatostanowymi i kwiatami o większej średnicy, a rośliny odmiany 'Suzy' większą liczbą kwiatów niż frezje pozostałych ocenianych odmian. Niezależnie od odmiany i dawki nawozu, najobficiej kwitnące, o najdłuższych kwiatostanach i pędach rośliny uzyskano stosując nawozy o spowolnionym działaniu Osmocote Plus i Osmocote Exact. Polyon nie nadaje się do nawożenia frezji, gdyż wpływa na znaczne obniżenie wartości ozdobnej roślin przez ograniczenie liczby wytwarzanych kwiatów, zmniejszenie ich średnicy, a także skrócenie i zniekształcenie kwiatostanów. 